\title{
Evaluation of DNA Plasmid Storage Conditions
}

\author{
Manabu Murakami*
}

Department of Pharmacology, Hirosaki University, Graduate School of Medicine, Aomori, Japan

\begin{abstract}
Several pBR DNA plasmid storage conditions were evaluated in this study, including the storage form (liquid or dried on 3M paper), the buffer used to dissolve the plasmid, and temperature. Storage in the liquid form resulted in increased colony formation compared to DNA dried on paper, which is a more convenient and often preferred method for shipping plasmids. The TE buffer was superior to autoclaved $\mathrm{H}_{2} \mathrm{O}$ for DNA storage. The most important factor for longterm storage was temperature, and storage at $-20^{\circ} \mathrm{C}$ in TE buffer showed good results (ca. $10^{7} \mathrm{cfu} / \mu \mathrm{g}$ plasmid DNA) for up to 270 days. In contrast, stored DNA plasmid in $\mathrm{H}_{2} \mathrm{O}$ or dried on What man $3 \mathrm{M}$ paper at $20^{\circ} \mathrm{C}$, preferred for ordinary DNA shipment, resulted in deteriorated yields after 90 days. In conclusion, my results indicate that $20^{\circ} \mathrm{C}$ is acceptable for short-term storage (up to 18days), but TE buffer and $-20^{\circ} \mathrm{C}$ should be used for longer-term storage.
\end{abstract}

Keywords: Plasmid, DNA, storage, temperature, transform, shipment.

\section{INTRODUCTION}

DNA storage is one of the most important factorsin DNA recombination experiments. Molecularbiology depends on several techniques, including DNA recombination, transformation, amplification, and storage. Therefore, DNA storage is important for many scientific investigations. In addition, plasmids are shipped worldwide. Therefore, identification of simple and stable DNA storage methods is critical. In the present study, DNA storage conditions, in terms of temperature, buffer type, and storage form, were evaluated for up to 270 days.

\section{MATERIAL AND METHODS}

Standard protocols were used for the molecular biological experiments [1]. Plasmid DNA was prepared with a Qiagen Midi-prep kit (Qiagen Inc., Valencia, CA, USA). Competent E. coli cells (XL-1blue; Stratagene Corp., La Jolla, CA, USA) were prepared using Inoue's protocol [2], which yields $10-100$ million cfu/ $\mu$ g and is one of the best protocols for preparation of competent cells. Inoue's protocol is an improved one of the widely used Hanahan's transformation protocol [3].

Three factors were evaluated, including the liquid or dried form of the DNA plasmid, TE buffer or autoclaved $\mathrm{H}_{2} \mathrm{O}$, and three temperatures $\left(20,4\right.$, and $\left.-20^{\circ} \mathrm{C}\right)$. Briefly, the pBR322 DNA plasmid (final concentration, $1 \mathrm{ng} / \mu \mathrm{l}$ ) was prepared in TE buffer (10 mM Tris-Cl, $\mathrm{pH} 7.5 ; 1 \mathrm{mM}$ EDTA) or autoclaved $\mathrm{H}_{2} \mathrm{O}$. Plasmid DNA (10 ng) was stored in a liquid or dried form, the latter on Whatmann 3M paper (WhatmannInc., Clifton, NJ, USA) $\left(\sim 2 \mathrm{~mm}^{2}\right)$ in a $0.5-\mathrm{ml}$ tube. After each storage period $(0,2,7,18,90,150,270$

*Address correspondence to this author at the Department of Pharmacology, Hirosaki University, Graduate School of Medicine, 5 Zaifucho, Hirosaki, Aomori, 036-8562, Japan; Tel: 81(172)395021; Fax: 81(172)395023;

E-mail: mmura0123@hotmail.co.jp days) at each temperature $\left(20,4\right.$, and $\left.-20^{\circ} \mathrm{C}\right)$, plasmid samples in paper form were soaked in $50-\mu \mathrm{l} \mathrm{H}_{2} \mathrm{O}$ at $4^{\circ} \mathrm{C}$ for $12 \mathrm{~h}$ to recover the plasmid. The same volume $(50 \mu \mathrm{l})$ of $\mathrm{H}_{2} \mathrm{O}$ was added to the liquid samples.

Approximately $1 \mathrm{ng}$ of each plasmid DNA sample was transformed on the same day. As transformation is often dependent on culture condition, all plasmid DNA was transformed on the same day using the same competent cell preparation. After $1 \mathrm{~h}$ incubation at $37^{\circ} \mathrm{C}$, one tenth of each sample was plated on a $90-\mathrm{mm}$ dish $\left(55 \mathrm{~cm}^{2}\right)$ containing ampicillin $(50 \mu \mathrm{g} / \mathrm{ml})$, and the colonies were enumerated the following day. With this protocol, colony number on one plate yields number $\times 10^{4} \mathrm{cfu} / \mu \mathrm{g}$ plasmid DNA, as it reflects colonies from $100 \mathrm{pg}$ of transformed plasmid DNA. The transformation efficiency of the control plasmid DNA was $1.34 \times 10^{7} \mathrm{cfu}$.

\section{STATISTICS}

Data are presented as means \pm standard error. Significance $(p<0.05)$ was determined by one-way or two-way analyses of variance. Student's $t$-tests were used when the means of two groups were compared. A $p$-value $<0.05$ was considered to indicate statistical significance.

\section{RESULTS AND DISCUSSION}

DNA quality was evaluated initially by electrophoresis (Fig. 1a). On day 18 at a storage temperature of $20^{\circ} \mathrm{C}$, electrophoresis clearly showed a significant decrease in DNA quantity, indicating time-dependent changes. Fig. (1b) shows typical results of plasmid transformation onday 90. The DNA plasmid in TE buffer (Fig.1b-i) yielded the greatest number of colonies, whereas DNA plasmid in $\mathrm{H}_{2} \mathrm{O}$ or dried on What man 3M paper (Fig. 1b-iv) resulted in relatively few colonies.

The difference between the liquid and dried DNAwas evaluated statistically (Fig. 1c). Storage as the liquid form 


\section{a. Plasmid DNA (in TE, at $20^{\circ} \mathrm{C}$ ) Days

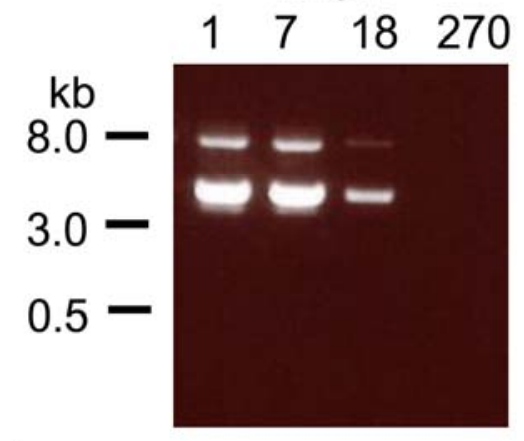 \\ b. Colony Formation (at $20^{\circ} \mathrm{C}$, on Day 90 )}
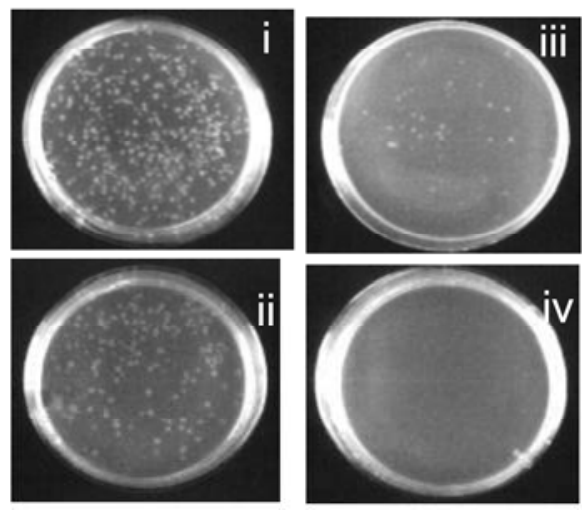

\section{1400 Liquid or Dried Form}

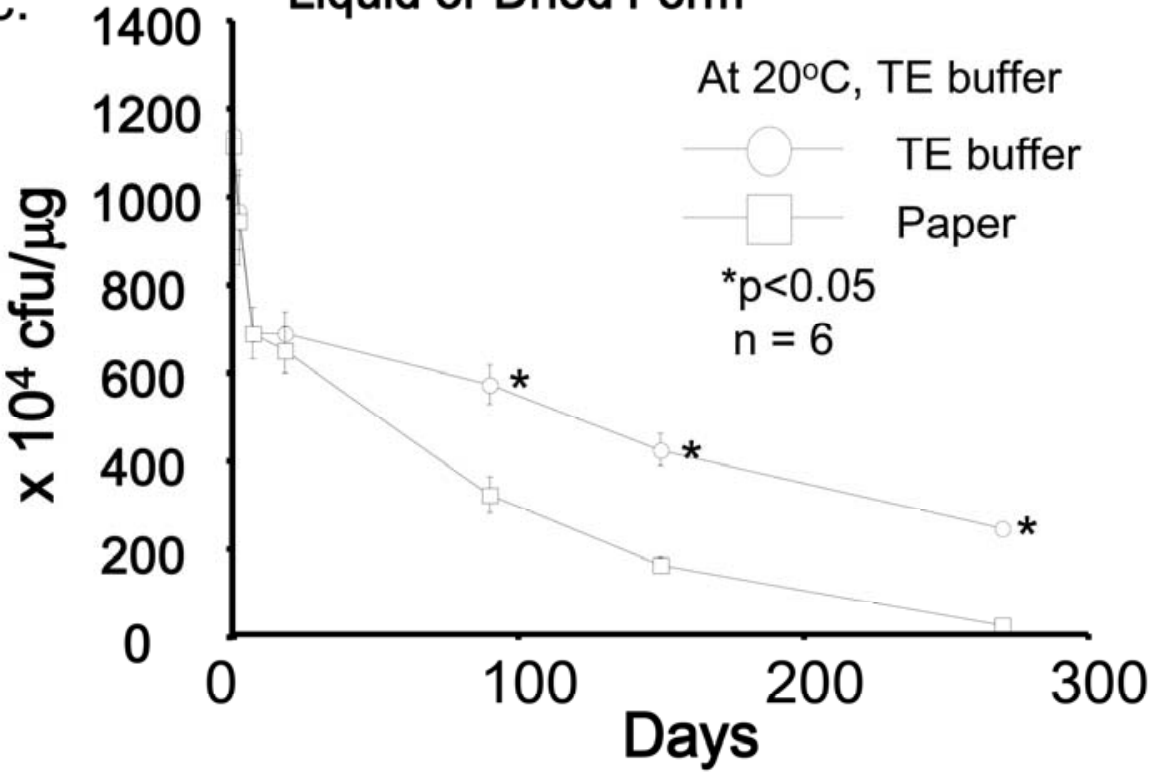

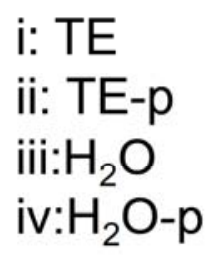

Fig. (1). Time-dependent changes of plasmid DNA in TE buffer.

a) Five $\mu \mathrm{l}$ of each sample were loaded. The number of storage days $(1,7,18$, and 270 days) is indicated. Plasmid DNA samples were stored in TE buffer at $20^{\circ} \mathrm{C}$.

b) Representative pBR plasmid DNA colony formation on day 90 .

Colony formation after transformation with plasmid DNA dissolved in TE (i), dried on 3M paper after dissolving in TE buffer (ii), dissolved in $\mathrm{H}_{2} \mathrm{O}$ (iii), and dried on $3 \mathrm{M}$ paper after dissolving in $\mathrm{H}_{2} \mathrm{O}$ (iv). Plasmid DNA samples were stored at $20^{\circ} \mathrm{C}$.

c) Time-dependent changes in colony formation of the liquid form (open circles) and dried form (open squares) of pBR plasmid DNA dissolved in TE buffer.

The liquid form of the plasmid resulted in significantly more colonies on days 90,150 , and 270 . Plasmid DNA samples were stored at $20^{\circ} \mathrm{C}$. $* p<0.05 v s$. dried form on paper, $\mathrm{n}=6$.

resulted in more colonies than the dried form ondays 90 , 150 , and $270\left({ }^{*} p<0.05, \mathrm{n}=6\right)$. Interestingly, no significant difference was observed between the two conditions on day18.

Next, buffer conditions were evaluated. TE buffer is thought to be better for DNA storage, as it is buffered to $\mathrm{pH}$ 7.5 and contains EDTA to chelate divalent ions; thus, TE buffer should be superior to autoclaved $\mathrm{H}_{2} \mathrm{O}$ for long-term storage. Indeed, TE buffer showed better results on days 90 , 150, and 270 (Fig. 2). No significant difference was observed on day18.

Temperature dependency was evaluated using the plasmid samples in TE buffer (Fig. 3). Use of $-20^{\circ} \mathrm{C}$ was beneficial for long-term storage. No significant decrease in colony number was observed on day 270 compared to that on day 0 (open blue circles). Storage at $4^{\circ} \mathrm{C}$ resulted in a timedependent decrease in colony number (open black circles). Storage at $20^{\circ} \mathrm{C}$ resulted in significantly decreased numbers of colonies on days 7,18, 90, 150, and 270 (open red circles). However, $>200$ colonies $\left(\mathrm{x} 10^{4} \mathrm{cfu} / \mu \mathrm{g}\right.$ ) were formed on day 270 under this storage condition. Nevertheless, the data revealed that $-20^{\circ} \mathrm{C}$ is the optimum temperature for long-term DNA plasmid storage.

The performance of the dried form of plasmid stored in TE buffer was also evaluated (Fig. 4). Colony number tended to decrease at $-20^{\circ} \mathrm{C}$ with this DNA plasmid storage form (open blue squares), although the difference was not significant. Storage as the dried form at 4 and $20^{\circ} \mathrm{C}$ resulted in decreased colony formation in a temperature-dependent manner; thus, these conditions are not suitable for long-term 


\section{Buffered form (TE) or $\left(\mathrm{H}_{2} \mathrm{O}\right)\left(20^{\circ} \mathrm{C}\right)$}

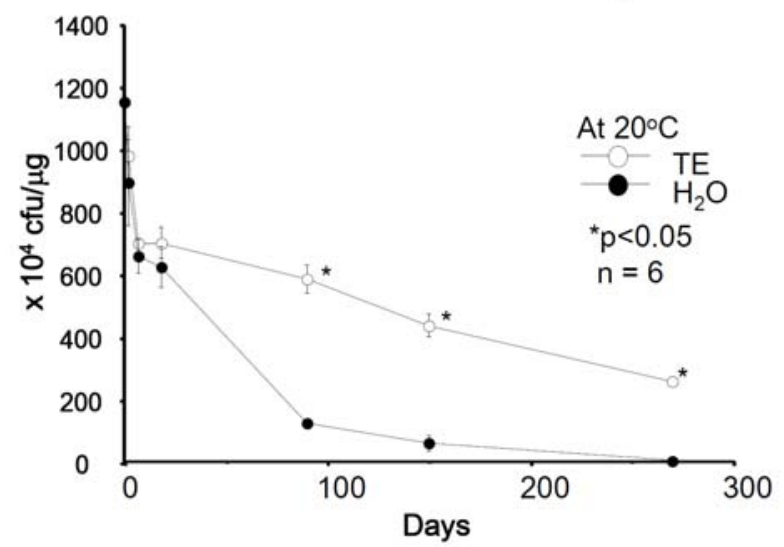

Fig. (2). Time-dependent changes in colony formation using various solutions.

Plasmid dissolved in TE buffer (open circles) resulted in significantly more colonies than that dissolved in autoclaved $\mathrm{H}_{2} \mathrm{O}$ (closed circles) on days 90, 150, and 270. Plasmid DNA samples were stored at $20^{\circ} \mathrm{C} .{ }^{*} p<0.05$ vs. plasmid dissolved in $\mathrm{H}_{2} \mathrm{O}, \mathrm{n}=6$.

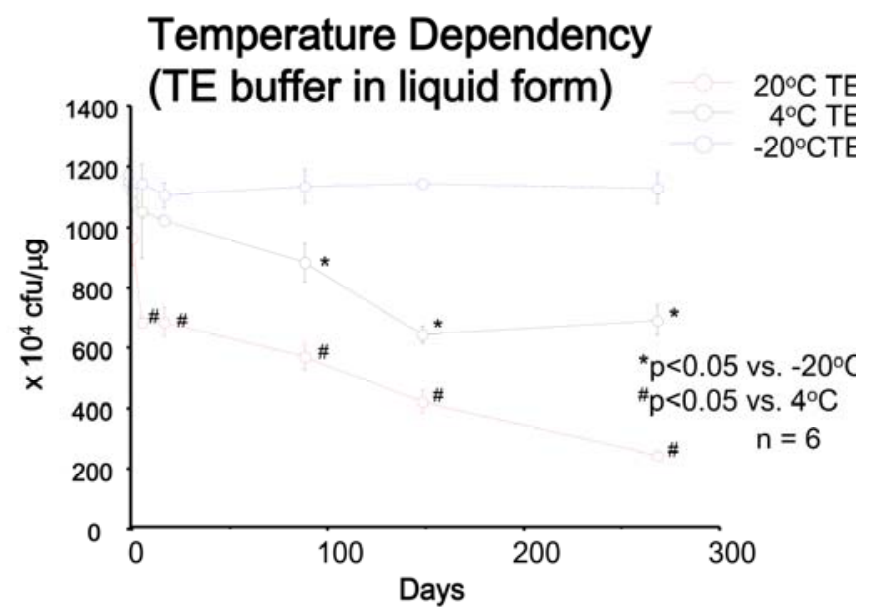

Fig (3). Time- and temperature-dependent changes in colony formation of liquid pBR plasmid DNA in TE buffer.

Different storage temperatures (red open circles, $20^{\circ} \mathrm{C}$; black open circles, $4^{\circ} \mathrm{C}$; and blue open circles, $-20^{\circ} \mathrm{C}$ ). pBR plasmid DNA was dissolved in TE buffer.

Plasmid DNA stored at $4^{\circ} \mathrm{C}$ resulted in significantly fewer colonies than that stored at $-20^{\circ} \mathrm{C}$ on days 90,150 , and 270 . Plasmid DNA stored at $20^{\circ} \mathrm{C}$ resulted in significantly fewer colonies than that stored at $4^{\circ} \mathrm{C}$ on days7, $18,90,150$, and $270 .{ }^{*} p<0.05 v s$. plasmid at $-20^{\circ} \mathrm{C}$. ${ }^{\#} p<0.05$ vs. plasmid at $4^{\circ} \mathrm{C}, \mathrm{n}=6$.

storage (particularly $20^{\circ} \mathrm{C}$ ). In addition, either few or no colonies were occasionally formed after plasmid recovery fromthe dried form. Taken together, these data indicate that any of the aforementioned conditions ( $\mathrm{TE}$ or $\mathrm{H}_{2} \mathrm{O}$, liquid or dried, three temperatures: 20,4 or $-20^{\circ} \mathrm{C}$ ) can be used to store plasmid DNA for 2 weeks, but the liquid form at $-20^{\circ} \mathrm{C}$ should be utilized for long-term storage. Considering the significant decrease in the number of colonies formed on day 90, DNA plasmids in the dried form should be recovered by

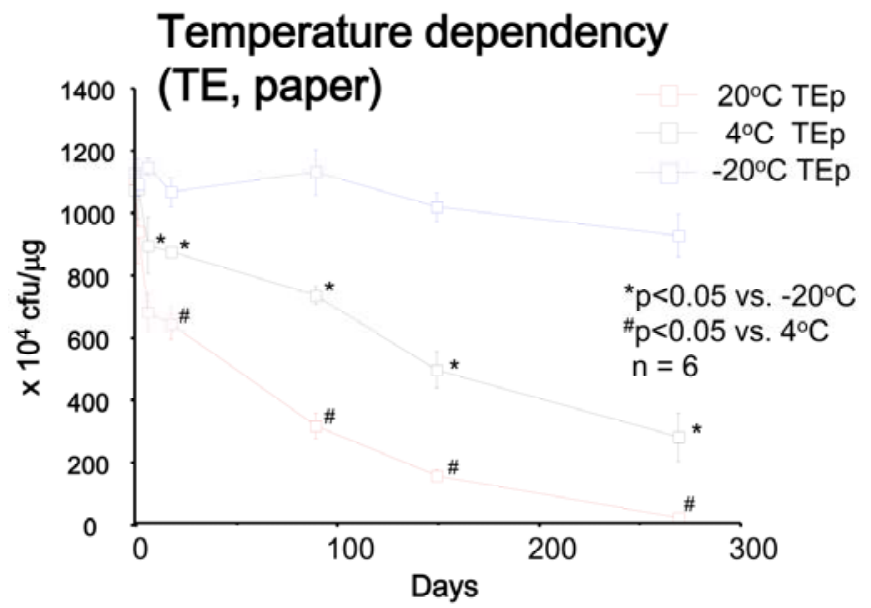

Fig. (4). Time- and temperature-dependent changes in colony formation by dried pBR plasmid DNA dissolved in TE buffer.

Different storage temperatures (red open squares, $20^{\circ} \mathrm{C}$; black open squares, $4^{\circ} \mathrm{C}$; and blue open squares, $-20^{\circ} \mathrm{C}$ ). pBR plasmid DNA was dissolved in TE buffer.

Plasmid DNA stored at $4^{\circ} \mathrm{C}$ resulted in significantly fewer colonies than that stored at $-20^{\circ} \mathrm{C}$ on days7, 18, 90, 150, and 270. Plasmid DNA stored at $20^{\circ} \mathrm{C}$ resulted in significantly fewer colonies than plasmid stored at $4^{\circ} \mathrm{C}$ on days18, 90, 150, and $270 .{ }^{*} p<0.05$ vs. plasmid at $-20^{\circ} \mathrm{C}$. ${ }^{\#} p<0.05$ vs. plasmid at $4^{\circ} \mathrm{C}, \mathrm{n}=6$.

day 18 (Fig. 4). This finding is important, if one considers plasmid shipment methods. My results indicate that plasmid DNA can be shipped in either the liquid or dried form at room temperature, but that it should be recovered within 2-3 weeks, transformed, and amplified. The amplified plasmid DNA should be maintained at $-20^{\circ} \mathrm{C}$ for long-term storage. In many laboratories, researchers send plasmid samples with Rosman's protocol, with TE buffer dried form at room temperature [4]. Our data indicate possible difficulties with the protocol, as I got only $169 \pm 18$ colonies $\left(\times 10^{4} \mathrm{cfu} / \mu \mathrm{g}\right)$ with modified Rosman's protocol (plasmid in TE buffer, dried form, at $20^{\circ} \mathrm{C}$, Fig. (4) red open square) on Day 150. Furthermore, I got mere $31 \pm 2$ colonies $\left(\mathrm{x} 10^{4} \mathrm{cfu} / \mu \mathrm{g}\right)$ on Day 270 (Fig. 4 red open square). Considering relatively unstable preparation of competent cells (sometimes less than $1 \times 10^{6}$ cfu/ $\mu$ g with Hanahan's protocol), it seems not advisable to stock plasmid DNA in the Rosman's condition for a longterm storage.

In conclusion, DNA plasmids in a liquid or dried form can be used for shipment, but should be maintained in liquid form at $-20^{\circ} \mathrm{C}$ for longer term storage of more than several weeks' duration.

\section{CONFLICT OF INTEREST}

The authors confirm that this article content has no conflicts of interest.

\section{ACKNOWLEDGEMENTS}

I thank Saki Nishimurafor her help. This study was sponsored by Grants-in-Aid for Scientific Research from JSPS, KAKENHI. 


\section{REFERENCES}

[1] Sambrook J, Russell DW. Eds.Molecular Cloning:A Laboratory Manual. $3^{\text {rd }}$ ed. Cold Spring Harbor NY; Cold Spring Harbor Laboratory 2001.

[2] Inoue H, Nojima H, Okayama H.High-efficiency transformation of Escherichia coli with plasmids.Gene 1990; 96: 23-8.
[3] Hanahan D, Jessee J, Bloom FR. Plasmid transformation of Escherichia coli and other bacteria. Methods Enzymol 1991; 204: 63113.

[4] Rosman GJ, Miller AD. Improved method for plasmid shipment. BioTechniques 1990; 8: 509

(C) Manabu Murakami; Licensee Bentham Open.

This is an open access article licensed under the terms of the Creative Commons Attribution Non-Commercial License (http://creativecommons.org/licenses/by-nc/3.0/) which permits unrestricted, non-commercial use, distribution and reproduction in any medium, provided the work is properly cited. 